\title{
NAPELEMEK LABORATÓRIUMI ÉS SZIMULÁCIÓS VIZSGÁLATA
}

\author{
Bodnár István \\ egyetemi adjunktus, Miskolci Egyetem, Fizikai és Elektrotechnikai Intézet \\ Elektrotechnikai és Elektronikai Intézeti Tanszék \\ Cím: 3515 Miskolc, Miskolc-Egyetemváros, e-mail: vegybod@uni-miskolc.hu \\ Matusz-Kalász Dávid \\ PhD hallgató, Miskolci Egyetem, Fizikai és Elektrotechnikai Intézet \\ Elektrotechnikai és Elektronikai Intézeti Tanszék \\ Cím: 3515 Miskolc, Miskolc-Egyetemváros,e-mail: elkmkd@uni-miskolc.hu
}

\begin{abstract}
Absztrakt
A napelemek hatásfokát számos tényezö befolyásolja. Többek között ilyen tényezö a külső és a napelem felületének hömérséklete. A kitüzött cél, a napelemek hömérsékletfüggése által okozott feszültség, áramerősség és teljesitmény értékek megváltozásának bemutatása. Két lehetöség adott, a numerikus szimuláció és a laboratóriumi mérés. Továbbá, a mérési eredmények képesek a szimulált értékek helyességét bizonyitani. A hömérsékletfüggés remek lehetöséget biztosit egy hütött és hütés nélküli napelem panel teljesitmény-megváltozásának vizsgálatára, állandó erösségü megvilágitás mellett.
\end{abstract}

Kulcsszavak: napelem, numerikus szimuláció, hömérsékletfüggés

\begin{abstract}
The efficiency of a solar panel is influenced by several factors. One of these factors are the ambient temperature together with the surface temperature. Our goal is to present the voltage, amperage, and power change of a solar panel caused by the temperature transient. There are two ways: the numeric simulation and the laboratory measurement. Furthermore, the measurement results can prove the correctness of the simulated results. Temperature transient gives us a chance to investigate cooled and non-cooled solar panel power changing, in case of constant intensity of illumination.
\end{abstract}

Keywords: solar panel, numeric simulation, temperature transient

\section{Bevezetés}

A 21. század első évtizede jelentős technikai forradalmat hozott, aminek hatására mára az emberek számos elektrotechnikai készülékkel és berendezéssel vették körül magukat. Ezek az eszközök természetesen villamos energiát igényelnek a folyamatos müködésükhöz. Ez a többlet energiaigény kimutatható az villamosenergia-szektor vizsgálatakor, mivel évröl-évre folyamatosan egyre több energiát igényel a hazai piac. Meg kell jegyezni, hogy a mindenkori igényt a felhasználás hatékonyságának növelése jelentős mértékben csökkenti. A lakossági összes többlet energiaigényt fedezni lehet a közcélú erőművi hálózat kapacitásának növelésével, valamint a háztartási kiserőmüvek mennyiségi növelésével egyaránt. Napjainkban egyre népszerübbek a napelemes háztartási 
kiserőmüvek, az elmúlt években rohamosan nő a beüzemelt rendszerek száma. A kutatás során a napelemekre gyakorolt számos környezeti és időjárási hatás közül a megvilágítás erősségének és a fényspektrum eloszlásának befolyásoló hatását kell kiemelni. Ezek laboratóriumi és szimulációs vizsgálata egyaránt szükséges, a kapott eredmények összehasonlítása, ellenőrzése miatt egyaránt.

\section{A napelem müködése}

A napelem müködésének megértéséhez a félvezetőkkel foglalkozó elméleti anyagot kell megismerni. Amikor a napból érkező foton energiája meghalad egy szükséges energiaszintet töltéshordozó párokat hoz létre. A napelem p-n átmenetében képződött feszültség szétválasztja az elektronokat és lyukakat, megakadályozza az úgynevezett rekombinációt. Az elektronok az n-réteg a lyukak a p-réteg irányába indulnak, ezzel létrejön a napelemben a fotoáram.

A napelem egyszerüsített elektronikai modellje (1. ábra) minden ohmikus és kapacitív elemet elhanyagolva egy diódából és egy vele párhuzamosan kapcsolt áramgenerátorból áll. Az elóállított áramerősség értéke a megvilágítás erősségétől függ. A napelem kivezetésein üresjárási feszültséget, és rövidzárási áramot mérhetünk, azonban, ha terhelést kapcsolunk rá, ezek az értékek kisebbek lesznek. $[1,2,5,6]$

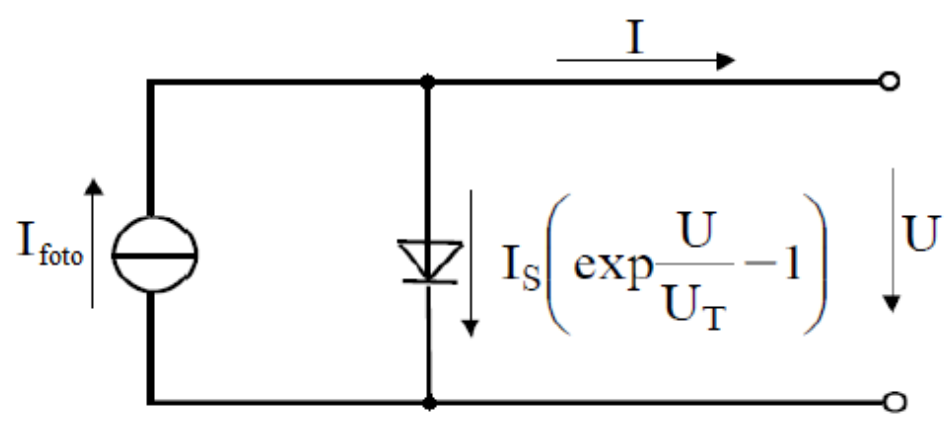

1. ábra. A napelem egyszerüsitett helyettesitö kapcsolása

A napelem kapcsaira kapcsolt terhelésen átfolyó I áramerősség és azon eső U feszültség szorzataként számolható a napelem $\mathrm{P}$ hasznos teljesítménye.

$$
P=I \cdot U=I_{S C} \cdot U-I_{S} \cdot U \cdot \exp \left(\frac{U}{U_{T}}-1\right)
$$

\section{A napelemek laboratóriumi vizsgálata}

\subsection{Napszimulátor}

A napszimulátorok minőségét osztályozó és előíró, IEC 60 904-9 szabvány 3 csoportot állapít meg, melyek közül az „A” csoport az napfényhez legközelebb álló fényt szolgáltat, és a „C” a leginkább eltérő megvilágítást. A tanszéki laboratóriumunkban található $8 \mathrm{db}$ halogénizzóból álló napszimulátor még a leggyengébb, C kategóriának sem felel meg, számos hiányossága miatt. A természetes napsugárzás intenzitása $1000 \mathrm{~W} / \mathrm{m}^{2}$. A megvilágított terület bizonyos részein az a mennyiség rendelkezésre áll, azonban az intenzitás jelentős inhomogenitást mutat. 


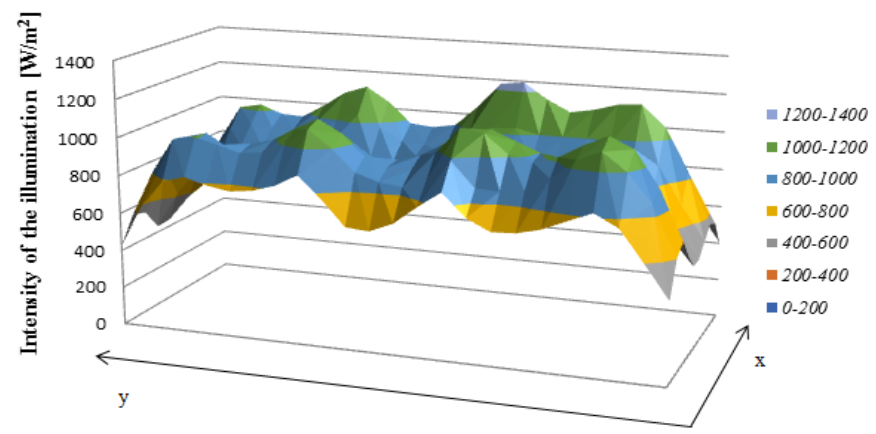

2. ábra. A megvilágitás intenzitásának eloszlása

Ez az inhomogenitás az alábbi összefüggéssel írható le [9]:

$$
\Delta E=\frac{E_{\max }-E_{\min }}{E_{\max }+E_{\min }} \cdot 100 \%
$$

ahol: $\Delta E-$ a megvilágítás inhomogenitásának mértéke [\%];

$E_{\max }-$ a maximális fényintenzitás értéke $\left[\frac{\mathrm{W}}{\mathrm{m}^{2}}\right]$;

$E_{\text {min }}-$ a minimális fényintenzitás értéke $\left[\frac{\mathrm{W}}{\mathrm{m}^{2}}\right]$.

A vizsgálatok során a következő értékeket mértük: $\mathrm{E}_{\max }=1,245 \mathrm{~W} / \mathrm{m}^{2}, \mathrm{E}_{\min }=407 \mathrm{~W} / \mathrm{m}^{2}$ and $\Delta \mathrm{E}=$ 50,73\%. A medián: $874 \mathrm{~W} / \mathrm{m}^{2}$, a módusz: $1000 \mathrm{~W} / \mathrm{m}^{2}$. A napelem felületét érő fényteljesítmény: 490,48 W. Továbbá a megvilágítás fényspektrumának eloszlása jelentős eltérést mutat a természetes fényspektrumhoz képest. A 3. ábrán jól látható ez az eltérés, ahol a direkt napsugárzás spektrumeloszlását a világoskék, amíg a napszimulátor direkt fényének spektrumeloszlását a sötétzöld görbe jelzi.

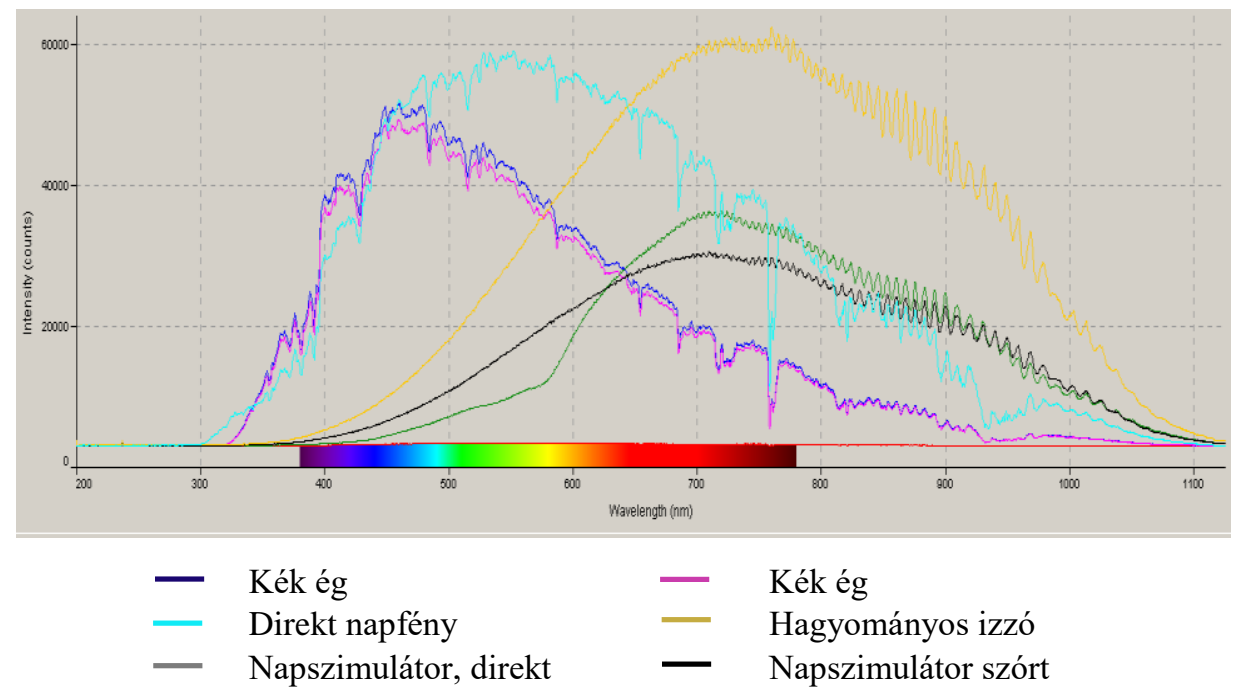

3. ábra. A különbözö fényforrások spektrális eloszlása 


\subsection{Mérési elrendezés}

A KS-85 típusú monokristályos napelem, a reflektorokból álló napszimulátor állványzata alá, egy asztalra lett helyezve. Mivel a reflektorok jelentős hőmennyiséget termelnek, a napelemek védelme érdekében hütést kellett biztosítani. Továbbá a hütésnek köszönhetően, kiszélesedett a vizsgálati lehetőség a hőmérsékletszabályozással, a hatásfok és teljesítményjavulás miatt. A megvilágított, de nem hütött napelem panel felülete akár a $80^{\circ} \mathrm{C}$ fokot is elérheti. A mobil klíma $15^{\circ} \mathrm{C}$-kal képes csökkeneti a felmelegedést, továbbá egy ventilátorral közösen már $40^{\circ} \mathrm{C}-\mathrm{kal}$, ami jelentős javulást eredményezett.

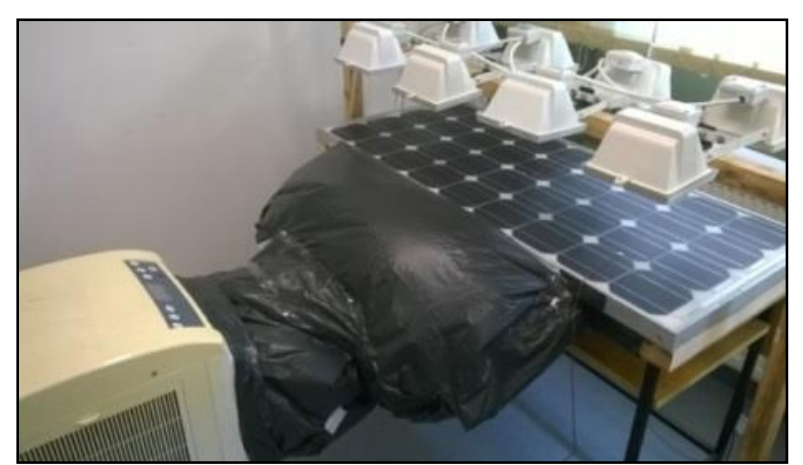

4. ábra. A napelem hütése mérés közben

\section{A szimuláció alapja}

A szimuláció során a kiindulási alapot a napelem egyszerüsített kapcsolási rajza jelentette. Számos konstans és adat képezi a szimuláció alapját, melyek többek között a vizsgált napelem elektrotechnikai paraméterei (pl. gyártói adatok).

A szimuláció során a következő megállapításokkal és elhanyagolással éltünk:

- a napelem egyetlen cellára való leredukálása,

- a soros és párhuzamos ellenállás elhanyagolása,

- a megvilágítás integrált átlaga lett figyelembe véve,

- a gyártó által megadott üresjárási feszültség, rövidzárási áram értékével és hőmérsékleti állandóval történő számítások,

- a halogén izzók fényének és a napfény spektrumeloszlása (spektrális energia sürüsége) közötti különbség állandó [2-6, 10].

\subsection{A módosított modell}

A módosított szimulációs modell a meglévő adatokon felül a mérési eredményeken alapuló hőmérsékleti állandókat tartalmaz. Továbbá, a módosított modell célja, hogy jobban közelítse a napelem öregedése által elöidézett a hatásfok csökkenést. A mérések során megállapított hőmérsékleti állandó a feszültség esetében megközelíti a gyártó által megadott adatot. Ellenben, az áramerősség esetében az értékek jelentős eltérést mutatnak. Ennek oka lehet mérési pontatlanág, vagy a megvilágítás hiányossága, mivel a napelemeket a természetes, nem pedig mesterségesen elóállított fény hasznosítására alkalmasak. Az eltérést a 3. ábrán látható spektrális összehasonlítás mutatja. 


\section{A mérési és szimulációs eredmények összehasonlítása}

Az áramerősség hőmérsékletfüggését a 5. ábra mutatja. A numerikus szimuláció során kapott adatok összhangban vannak a mért étékekkel. A mérési adatok görbéje számszerüleg sokkal közelebb áll a módosított szimulációs modell által szolgáltatott adatokhoz. Az átlagos eltérés 1,38\%. Azonban, ha a tendenciát vesszük figyelembe az alap modellel kapott eredmények hasonlóbbak (az átlagos eltérés 4,14\%). Mindhárom görbén jól kivehető a hütés bekapcsolásának hatása, ami jelentős áramerősség esést eredményezett. Az eredmények nagyon hasonlóak, mint Singh és társának [11], valamint Malik és társainak [13] kutatási eredményei.

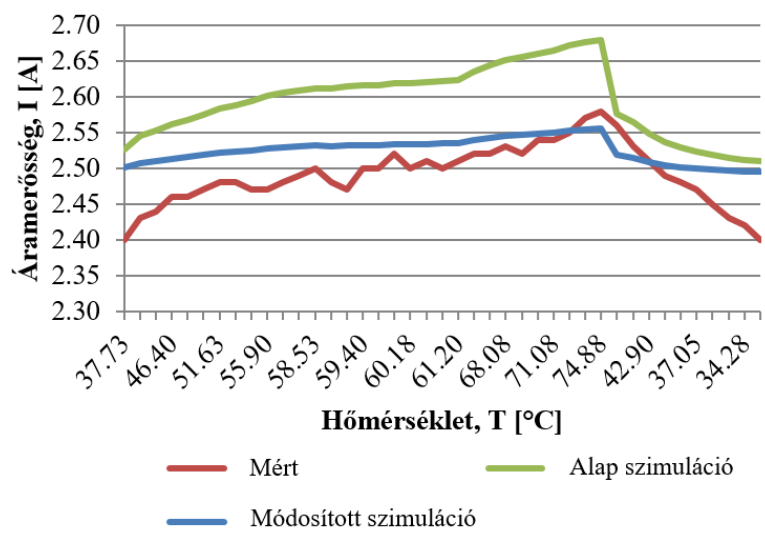

5. ábra. A napelem áramerösségének hömérsékletfüggése

A következő 6. ábra a feszültség és hőmérséklet kapcsolatát mutatja. Jól látható, hogy alacsonyabb hőmérséklet tartományban a módosított szimulációs modell a mérési értékekkel szinte azonos eredményeket generált. $60^{\circ} \mathrm{C}$ felett a görbék eltávolodnak egymástól, az értékek közötti eltérés nagyobb lett. Az alap modell esetében az átlagos eltérés 5,98\%, amíg a módosított modell esetében csak 2,52\%. A hütés bekapcsolásának hatása a feszültség-hőmérséklet görbe esetében is jól leolvasható, mindhárom görbe meredek feszültség növekedést mutat. Az eredmények nagyon hasonlóak, mint Singh és társának [11], Chantana és társainak [12], valamint Malik és társainak [13] kutatási eredményei.

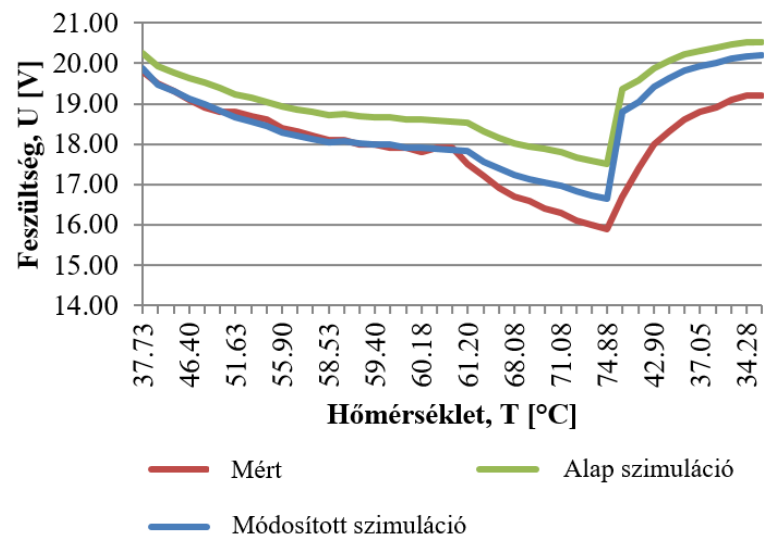

6. ábra. A napelem feszültségének hömérsékletfüggése 
A 7. ábra az elméleti teljesítmény görbéket mutatja, melyek számított értékek. A görbék kezdeti szakasza csökkenő, a hőmérséklet növekedésével fordított arányosságban. A teljesítmény görbék tendenciája a feszültség görbékével azonos, mivel az áramerösség kicsi, néhány tized amperes változást mutatott, addig a feszültség lényegesen nagyobb váltakozást. Továbbá a feszültség érték az áramerősség értékének nyolcszorosa. Az előző két ábrához hasonlóan, ha hütés hatása a feszültséghőmérséklet görbékhez hasonlóan jól megfigyelhető. Az alap szimulációs modell 10,43\%-os eltérést mutat, amíg a módosított modell esetében az eltérés 3,92\%.

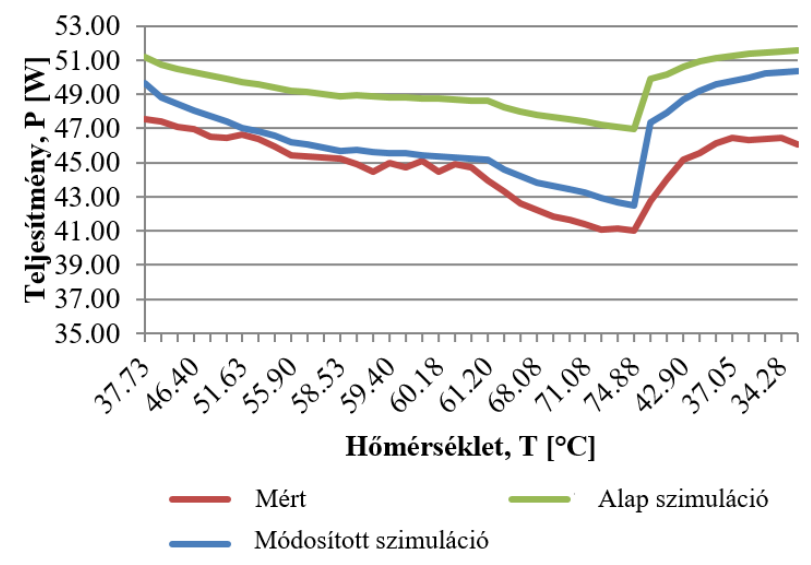

7. ábra. A napelem teljesitményének hömérsékletfüggése

Az 1. táblázat összegzi a tapasztalt eltéréseket a mérés, valamint a két szimulációs modell esetén. A grafikonokból is látszik, továbbá ezt megerősítendő, hogy a módosított szimuláció jobban közelítette a mérési eredményeket. A módosított szimuláció adatainak átlagos eltérése a méréstől jellemzően az alap modell eltérés értékeinek kevesebb, mint fele.

1. táblázat. A két szimulációs eljárás eredményeinek a mérési eredményektöl való eltérése

\begin{tabular}{|c|c|c|c|c|c|c|c|c|}
\hline & \multicolumn{4}{|c|}{ Szimuláció (alap) } & \multicolumn{3}{c|}{ Szimuláció (módosított) } \\
\cline { 2 - 9 } & $\begin{array}{c}\text { Min } \\
{[\%]}\end{array}$ & $\begin{array}{c}\text { Max } \\
{[\%]}\end{array}$ & $\begin{array}{c}\text { Medián } \\
{[\%]}\end{array}$ & $\begin{array}{c}\text { Átlag } \\
{[\%]}\end{array}$ & $\begin{array}{c}\text { Min } \\
{[\%]}\end{array}$ & $\begin{array}{c}\text { Max } \\
{[\%]}\end{array}$ & $\begin{array}{c}\text { Medián } \\
{[\%]}\end{array}$ & $\begin{array}{c}\text { Átlag } \\
{[\%]}\end{array}$ \\
\hline $\mathbf{I}_{\mathbf{S C}}$ & 0.66 & 5.84 & 4.59 & 4.14 & -1.71 & 4.20 & 1.31 & 1.38 \\
\hline $\mathbf{U}_{\mathbf{O C}}$ & 2.20 & 15.92 & 4.52 & 5.98 & -0.87 & 12.58 & 0.63 & 2.52 \\
\hline $\mathbf{P}$ & 6.60 & 16.68 & 9.91 & 10.34 & 0.66 & 10.77 & 2.93 & 3.92 \\
\hline
\end{tabular}

\section{6. Összefoglalás}

A szimulált és mért feszültség-áramerősség értékek összhangban vannak a mások által kapott értékekkel. Továbbá a szimuláció helyes megközelítést bizonyítja a mérési eredményekkel való összevethetősége. A két elektrotechnikai jellemző hőmérséklet függése jól mérhetőnek, és szemléltethetőnek bizonyult, ezzel visszaigazolva a szakirodalmat. A hütés hatására a fellépő meredek változások, melyek közül a teljesítmény növekedést kell kiemelni, indokolják további kutatások elvégzését a témában. Ezt alátámasztva elegendő, ha arra gondolunk, hogy egy megfelelő hütés energiaigényét a teljesítménynövekedés fedezheti, sőt meg is haladhatja, valamint a túlmelegedés elkerülésével a napaelem élettartama növekszik. 
Ugyanakkor meg kell jegyezni, hogy a laboratóriumban elóállítható megvilágítás jelentős eltérést mutat a természetes napfényhez képest, elsősorban a spektrumeloszlás tekintetében. Azonban az időjárás szeszélyességére, a nem ideális naptári időszakra és a vizsgálatok megismételhetőségét figyelembe véve a napszimulátor használata volt a legjobb választás. [7-9].

\section{Köszönetnyilvánítás}

A cikkben ismertetett kutató munka az EFOP-3.6.1-16-2016-00011 jelű „Fiatalodó és Megújuló Egyetem - Innovatív Tudásváros - a Miskolci Egyetem intelligens szakosodást szolgáló intézményi fejlesztése" projekt részeként - a Széchenyi 2020 keretében - az Európai Unió támogatásával, az Európai Szociális Alap társfinanszírozásával valósul meg.

\section{Irodalom}

[1] Hersch, P.: Basic photovoltaic principles and methods. United States Department for Energy. USA, 1982. p. 55. https://doi.org/10.2172/5191389

[2] Szász, Cs.: Optimal control of Photovoltaic Modules Energy Efficiency. Journal of Computer Science and Control Systems. Vol. 10. No. 1. 2017. pp. 29-34.

[3] Chan, D.S.H., Phang, J.C.H.: Analytical methods for the extraction of solar-cell single- and double-diode model parameters from I-V characteristics. IEEE Transactions on Electron Drives. Vol. 34. No. 2. 1987. pp. 286-293. https://doi.org/10.1109/T-ED.1987.22920

[4] Ishaque, K., Salam, Z., Taheri, H.: Simple, fast and accurate two-diode model for photovoltaic modules. Solar Energy Materials and Solar Cells, Vol. 95. No. 2. 2011. pp. 586-594. https://doi.org/10.1016/j.solmat.2010.09.023

[5] Kurobe, K., Matsunami, H.: New two-diode model for detailed analysis of multicrystalline silicon solar cell. Japanese Journal of Applied Physics, Vol. 44. 2005. pp. 8314-8321. https://doi.org/10.1143/JJAP.44.8314

[6] Ishaque, K., Salam, Z., Taheri, H., Syafaruddin: Modelling and simulation of photovoltaic (PV) sys-tem during partial shading based on a two-diode model. Simulation Modelling Practice and Theory, Vol. 19. No. 7. 2011. pp. 1613-1626. https://doi.org/10.1016/j.simpat.2011.04.005

[7] Siddiqui, R., Kumar, R., Jha, K.G., Morampudi, M., Rajput, P., Lata, S., Agariya, S., Nanda, G., Raghava, S.S.: Comparison of different technologies for solar PV (Photovoltaic) outdoor performance using indoor accelerated aging tests for long term reliability. Energy. Vol. 107. No. 15. 2016. pp. 550-561. https://doi.org/10.1016/j.energy.2016.04.054

[8] Munoz-Garcia, M.A., Marin, O., Alonso-García, M.C., Chenlo, F.: Characterization of thin film PV modules under standard test conditions: Results of indoor and outdoor measuremnets and the effects of sunlinght exposure. Solar Energy. Vol. 86. No. 10. 2012. pp. 3049-3056. https://doi.org/10.1016/j.solener.2012.07.015

[9] Földváry, Á.: Napelemek laboratórium. Budapest University of Technology and Economics. Perfor-mance materials. 2015. p. 32.

[10] Pareja-Aparicio, M., Pelegrí-Sebastia, J., Sogorb, T., Llario, V.: Modeling of Photovoltaic Cell 267 
Using Free Software Application for Training and Design Circuit in Photovoltaic Solar Energy. INTECH World's largest Science, Technology \& Medicine Open Access book publisher. Chapter 6. 2013. p. 21. https://doi.org/10.5772/51925

[11] Singh, P., Ravindra, N.M.: Temperature dependence of solar cell performance - an analysis. Solar Energy Materials and Solar Cells. Vol. 101. 2012. pp. 36-45. https://doi.org/10.1016/j.solmat.2012.02.019

[12] Chantana, J., Kato, T., Sugimoto, H., Minemoto T.: Time-resolved photoluminescence of $\mathrm{Cu}(\mathrm{In}, \mathrm{Ga})(\mathrm{Se}, \mathrm{S}) 2$ thin films and temperature dependent current density-voltage characteristics of their solar cells on surface treatment effect. Current Applied Physics. Vol. 17. No. 4. 2017. pp. 461-466. https://doi.org/10.1016/j.cap.2017.01.006

[13] Malik, A.Q., Ming, L.C., Sheng, T.K., Blundel, M.: Influence of Temperature on the Performance of Photovoltaic Polycrystalline Silicon Module in the Bruneian Climate. AJSTD Vol. 26 No. 2 2010. pp. 61-72. https://doi.org/10.29037/ajstd.322 